\title{
PENCEMARAN NAMA BAIK: KAJIAN LINGUISTIK FORENSIK
}

\author{
Mintowati \\ Universitas Negeri Surabaya, mintowati@yahoo.co.id
}

\begin{abstract}
This paper aims to discuss lingual data of defamation cases based on analysis, lexical semantics, grammatical semantics, and pragmatic analysis (speech acts) which are part of linguistic forensic studies. From the lingual data on defamation that has been analyzed based on the three points of view, the following findings are obtained: (1) based on the lexical semantic analysis found the lexical meaning / meaning of word denotation; (2) based on the grammatical semantic analysis, the meaning of phrases, sentences, and discourse in accordance with the intended by the speaker; (3) there are speech acts of illocution and expressive perlokusi, both from speakers and partners said. Based on the results of the analysis it can be concluded that a speech is classified as defamation and this can be utilized by the investigator as one of the basis for the preparation of the investigation event (BAP) as well as the decision making for the legal sanction for the defamation perpetrator.
\end{abstract}

Key words: defamation, lexical semantics, grammatical semantics, speech acts of illocution and perlocution, forensic linguistics

\section{PENDAHULUAN}

Linguistik merupakan disiplin ilmu kebahasaan yang terus berkembang. Berdasarkan kajiannya, linguistik diklasifikasikan menjadi mikrolinguistik yang melingkupi fonologi, morfologi, sintaksis, dan semantik dan makrolinguistik yang melingkupi sosiolinguistik, psikolinguistik, neurolinguistik, linguistik forensik, dan lain-lain. Dari sejumlah kajian linguistik tersebut, neurolinguistik dan linguistik forensik merupakan subdisiplin linguistik yang relatif masih belum banyak didalami oleh para linguis, khususnya di Indonesia.

Salah satu kajian linguistik forensik yang menarik adalah kajian terhadap kasus pencemaran nama baik. Dalam makalah ini dibahas data lingual tentang pencemaran nama baik, khususnya kasus yang terjadi di media sosial. Hal ini dilakukan mengingat pencemaran nama baik di media sosial facebook, twitter, path, blog, dan lainnya merupakan kasus yang akhir-akhir ini sering terjadi 
dengan pelaku mulai dari masyarakat awam sampai dengan pejabat. Adapun sasaran pencemaran nama baik juga beragam, dari pelajar sampai dengan pejabat.

Dalam Undang-Undang Informasi dan Transaksi Elektronik (UU ITE) Nomor 11 Tahun 2008 pasal 27 ayat 3 disebutkan, "Setiap orang dengan sengaja dan tanpa hak mendistribusikan dan/atau mentransmisikan dan/atau membuat dapat diaksesnya informasi elektronik dan/atau dokumen elektronik yang memiliki muatan penghinaan dan/atau pencemaran nama baik" merupakan perbuatan melawan hukum. Dalam kutipan tersebut, dinyatakan bahwa siapapun yang dengan sengaja mengirimkan pesan yang memuat unsur penghinaan dan/atau pencemaran nama baik melalui media elektronik sehingga dapat diakses oleh banyak orang, hal itu merupakan perbuatan melawan hukum. Pencemaran nama baik bisa dilaporkan sebagai perbuatan melawan hukum.

Terdapat sejumlah kasus pencemaran nama baik yang dilaporkan ke kepolisian, misalnya "Dituduh Menghina Lewat Facebook, Ujang Dilaporkan ke Polisi Bogor" (2009), "Farah Dihukum karena Mencaci lewat Facebook" (2009), "Bupati Karawang Jabar Gerah Kritikan Fecebooker" (2011), "Bupati Pasaman Barat, Sumbar, Polisikan Pengguna Facebook" (2012), "Warga Sukorejo Dilaporkan ke Polisi karena Komentar di Facebook" (2012), "Prita Mulyasari Ditahan karena Email Keluhkan Layanan Rumah Sakit" (2014), "Iwan Piliang Dilaporkan Anggota DPR" (2014), "Status Facebook Menghina Orang Bali" (2014), "Dihina di Facebook, Bupati Kutai Timur Pidanakan Warganya” (2014), "Florence Sihombing Hina Yogya di Path" (2014), dan masih banyak lagi. Dari sejumlah kasus tersebut, pelapor berasal dari orang awam, pelajar, anggota DPR, hingga bupati. Dari pihak terlapor, ada orang awam, guru, pacar, dan jurnalis. Dari sejumlah kasus tersebut, ada yang diputus bebas, ada yang menggantung, tetapi banyak yang diputus hukuman penjara. Yang diputus hukuman penjara, hinaan yang mereka lakukan melalui media sosial tersebut terbukti mencemarkan nama baik pihak pelapor.

Dari sejumlah kasus pencemaran nama baik, penulis memilih dua data dari pemberitaan online, yakni kasus Florence Sihombing (2014) dan kasus Ervani Emihandayani (2014). Pada kasus pertama, pelaku adalah seorang mahasiswa S2 198 | E-ISSN: 2527-8754 http:// journal.unesa.ac.id/index.php/Paramasastra 
Universitas Gajah Mada juga menulis status di Facebook dan pada akhirnya diputus hukuman penjara, sedangkan pada kasus kedua, pelaku adalah seorang ibu rumah tangga yang menulis status di Facebook dan pada akhirnya diputus bebas. Pemilihan sumber data didasari oleh kelengkapan ulasan di media massa online, kedua kasus tersebut menarik perhatian masyarakat luas, pelaku pertama adalah mahasiswa S2 yang sedang studi lanjut S2 Ilmu Kenotariatan Fakultas Hukum UGM, yang notabene sadar hukum, sedangkan pelaku pada kasus kedua seorang ibu rumah tangga, yang notabene tidak atau kurang sadar hukum.

Pembahasan dilakukan dengan menggunakan metode deskriptif-analitis. Penyediaan data dilakukan dengan metode dokumentasi dengan teknik baca dan catat. Data linguistis pada kedua kasus tersebut dianalisis dengan teori Semantik dan Pragmatik (Tindak Tutur).

\section{PEMBAHASAN}

Hakikat Linguistik Forensik

Linguistik forensik merupakan subdisiplin linguistik yang mengaji linguistik dan hukum atau linguistik dan isu-isu legal (Turrell, 2008). Istilah "forensic English” digunakan pertama kali oleh F.A. Philbrick pada 1949 (dalam Turrell, 2008) dalam buku yang berjudul Language and the Law: The Semantics of Forensic English. Lebih lanjut, J. Svartvik (1968) memunculkan istilah "lingustik forensik" dalam karyanya yang berjudul The Evans Statement: A Case for Forensic Linguistics.

Menurut Coulthard dan Jonhson (2010), kajian linguistik forensik meliputi (1) bahasa dalam dokumen resmi, (2) bahasa penegak hukum dan polisi, (3) interaksi di ruang pengadilan, (4) interviu antara anak-anak dengan saksi dalam sistem legal, (5) bukti linguistik dan testimoni saksi ahli di ruang pengadilan, (6) atribusi menulis dan plagiasi, dan (7) fonetik forensik serta identifikasi penutur. Masih menurut Coulthard dan Johnson (2010), pakar linguistik forensik memiliki tugas mengungkap (1) makna morfologis dan similaritas fonetik, (2) kompleksitas sintaktik dalam surat resmi, (3) ambuguitas leksiko-gramatikal, (4) makna 
leksikal, dan (5) makna pragmatik. Berangkat dari pendapat tersebut, tulisan ini bermaksud menganalisis kasus pencemaran nama baik dengan menggunakan analisis semantik-pragmatik.

\section{Pencemaran Nama Baik}

Pencemaran nama baik, dalam KUHP, disebut juga penghinaan. Pencemaran nama baik dalam bahasa Inggris disebut sebagai defamation. Perbuatan tersebut merupakan hal yang bisa dilaporkan ke kepolisian, karena ada pihak yang merasa dirugikan, yakni nama baiknya dicemarkan atau kehormatannya dilecehkan, bahkan dirusak.

Dalam Hukumonline, dijelaskan pencemaran nama baik dalam UU TIIE pasal 27 ayat (3) bukan delik biasa ditinjau dari segi esensi delik penghinaan dan aspek historis. Dari esensi penghinaan, pencemaran nama baik dinyatakan sebagai perbuatan menyerang nama baik seseorang atau kehormatan yang berdampak pada pencemaran atau perusakan nama seseorang atau pihak-pihak yang dirugikan. Konten dan konteks tuturan atau tulisan seseorang yang ditujukan kepada pihak tertentu dikatakan sebagai perbuatan "menyerang" nama baik hanya dipahami oleh korban serangan pencemaran nama baik, karena merekalah yang merasakan dihina, terhina, terlecehkan (Sitompul, 2012). Di sisi lain diketahui, undang-undang memberikan perlindungan hukum terhadap harkat dan martabat warga negara sebagai hak asasi manusia.

Ditambahkan oleh Hukumonline bahwa konteks berfungsi menilai secara objektif konten penghinaan. Konteks yang dimaksud meliputi bagaimana perasaan pihak yang "diserang” dan bagaimana perasaan pihak yang "menyerang”, tujuan "penyerang" menyebarkan penghinaan tersebut. Berdasarkan hal tersebut, untuk menangkap konteks terhadap konten hinaan diperlukan pakar bahasa, pakar psikologi, dan pakar komunikasi.

Selanjutnya, aspek historis, pasal 27 ayat (3) UU ITE, jika ditinjau berdasarkan Kitab Undang-Undang Hukum Pidana (KUHP), pasal 310 dan pasal 311, dinyatakan bahwa penghinaan termasuk dalam delik aduan. Hal ini diperkuat dengan Putusan Mahkamah Konstitusi Nomor 50/PUU-VI/2008. Dari kedua 200 | E-ISSN: 2527-8754 http:// journal.unesa.ac.id/index.php/Paramasastra 
pernyataan hukum tersebut, penghinaan merupakan delik aduan, bukan delik biasa.

Hasil Analisis

Kasus Florence Sihombing (FS): Analisis Semantik Leksikal, Semantik Gramatikal, dan Tindak Tutur

Data lingual FS merupakan salah satu data kajian Linguistik Forensik. Berikut ini, data lengkap yang diunggah di Path milik FS (@www.tribunnews.com).

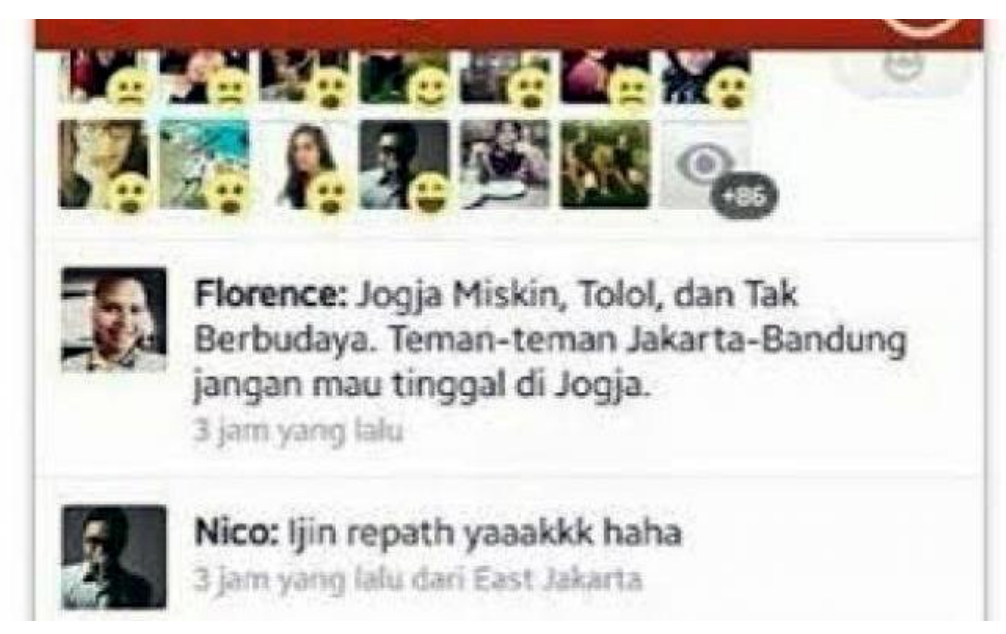

Data lingual tersebut dianalisis berdasarkan semantik leksikal. Semantik leksikal adalah salah satu cabang Semantik. Ia memelajari makna kata secara lepas, tanpa mengaitkan kedudukan kata dalam kalimat (Chaer, 2009). Kata-kata dalam path FS adalah "miskin" dan "tolol". Kata tersebut ditulis dengan huruf awal kapital sebagai penekanan. Kata "miskin" dalam Kamus Besar Bahasa Indonesia daring (2016) bermakna leksikal: tidak berharta, serba kekurangan (berpenghasilan sangat rendah). Kata kedua adalah “tolol”. Dalam Kamus Besar Bahasa Indonesia daring (2016), kata “tolol” bermakna sangat bodoh; bebal. Dari 
analisis secara leksikal tersebut, sangat jelas jika kedua kata tersebut bermakna negatif dan rendah.

Dari segi semantik gramatikal, yakni semantik yang memelajari makna frasa, klausa, dan kalimat, FS menulis frasa "tidak berbudaya" dan dua buah kalimat, yaitu (1) "Jogja Miskin, Tolol, dan Tidak Berbudaya" dan "Teman-teman Jakarta-Bandung jangan mau tinggal di Jogja." Frasa "tidak berbudaya" dibentuk dari dua kata, yakni "tidak" dan "berbudaya". Dengan demikian, frasa tersebut bermakna tidak memiliki budaya, tidak memiliki pikiran dan akal yang maju (Kamus Besar Bahasa Indonesia daring, 2016).

Selain itu, tuturan "Jogja Miskin, Tolol, dan Tidak Berbudaya” merupakan kalimat majemuk setara. Kalimat tersebut berasal dari tiga kalimat, yaitu (1) “Jogja Miskin”, (2) “Jogja Tolol”, dan “Jogja Tidak Berbudaya”. Ketiga kalimat tersebut bersubjek sama, yakni "Jogja". Sebagaimana diketahui, "Jogja" merupakan ibu kota Provinsi Daerah Istimewa Yogyakarta. Pemimpin provinsi tersebut adalah Sultan Hamengku Buwana X. Sebagai ibu kota provinsi, Yogyakarta jelas memiliki rakyat. Karena itu, kata "miskin" dan "tolol” serta frasa "tidak berbudaya" dikenakan pada seluruh rakyat Yogyakarta beserta para pemimpin provinsi tersebut. Berdasarkan analisis semantik leksikal dan gramatikal, tuturan FS bermakna "rakyat dan pemimpin Yogyakarta adalah rakyat dan pemimpin yang sangat bodoh dan bebal; tidak memiliki budaya dan tidak memiliki pikiran dan akal yang maju". Hal tersebut didukung oleh ahli bahasa dari Fakutas Bahasa dan Sastra UNY Ibnu Santoso (2015) yang menyatakan bahwa kata "tolol" dan "tak berbudaya" adalah kata-kata untuk menghina dan merendahkan.

Analisis berikutnya dilakukan dengan pendekatan pragmatik. Dalam data tersebut, FS menulis, “ Jogja Miskin, Tolol, dan Tak Berdudaya. Teman-teman Jakarta-Bandung jangan mau tinggal di Jogja." Berdasarkan konteks, yang diserang oleh FS adalah "Jogja". Kepada "Jogja" FS mengatakan "miskin", “tolol", dan "tak berbudaya". Berdasarkan teori tindak tutur (Searle, 1965), yang dituturkan oleh FS merupakan tindak tutur ilokusi ekspresif. FS mengekspresikan kekecewaan dan kemarahannya kepada "Jogja”. Bahkan menurut Kabid Humas 202 | E-ISSN: 2527-8754 http:// journal.unesa.ac.id/index.php/Paramasastra 
Polda DIY, AKBP Anny Puji Astuti, tuturan FS tersebut merupakan tuturan ekspresif yang provokatif. Hal berikutnya adalah tuturan FS yang berbunyi, "Teman-teman Jakarta-Bandung jangan mau tinggal di Jogja" merupakan tindak tutur direktif, berupa ajakan. Melalui tuturan tersebut, FS mengajak dan memprovokasi teman-temannya yang berdomisili di Jakarta dan Bandung agar tidak tinggal di Yogyakarta.

Tuturan ilokutif-ekspresif tersebut menuai perlokusi berupa dilaporkannya FS oleh LSM Jangan Khianati Suara Rakyat (Jati Sura) ke pihak kepolisian. Sebagai akibatnya, FS ditahan oleh Polda DIY berdasarkan KUHAP dan prosedur penahanan dalam UU ITE (merdeka.com, 1/9-2014). Tuturran FS di path miliknya sebagai ungkapan kekecewaannya karena dia harus mengantre BBM di SPBU Lempuyangan. Padahal, waktu itu antrean sedang padat dan sedang terjadi kelangkaan BBM (Hanafi, 2014b).

Tuturan kedua yang dibahas adalah "Teman-teman Jakarta-Bandung jangan mau tinggal di Jogja." Tuturan tersebut ditujukan kepada teman-teman FS yang berdomisili d Jakarta dan Bandung. Dari semantik gramatikal dan konteks, tuturan FS tersebut bermotif provokatif. Melalui tuturan tersebut, FS memprovokasi teman-temannya supaya tidak tinggal di Yogyakarta.

Berdasarkan analisis semantik leksikal, gramatikal, dan teori tindak tutur, tuturan FS merupakan tuturan yang bermuatan pencemaran nama baik. Sebagai hasil akhir dari kasus tersebut adalah yang bersangkutan (FS) divonis majelis hakim PN Yogyakarta dengan hukuman dua bulan penjara dengan masa percobaan enam bula dan wajib membayar denda sebesar 10 juta rupiah subsidair satu bulan kurungan. Banding yang dilakukan FS pun ditolak oleh Pengadilan Tingggi Yogyakarta, bahkan vonis tersebut justru diperkuat (Hanafi, 2015b).

Kasus Ervani Emihandayani (EE): Analisis Semantik Leksikal, Semantik Gramatikal, dan Tindak Tutur

Data lingual dalam kasus pencemaran nama baik berikut ini di-posting oleh Ervani Emihandayani (EE) di akun Facebook. Posting-an tersebut berbunyi sebagai berikut. 
"Iya sih Pak Har baik, yang nggak baik itu yang namanya Ayas dan Spv lainnya. Kami rasa dia nggak pantas dijadikan pimpinan Jolie Jogja Jewellery. Banyak yang lebay dan masih labil seperti anak kecil!" Akibat posting-an tersebut, EE dilaporkan oleh mantan rekan kerja sang suami (Hanafi, 2014a). Oleh polisi, dia dijerat Pasal 45 ayat (1) jo Pasal 27 ayat (3) Undang-undang Nomor 11 Tahun 2008 tentang Informasi dan Transaksi Elektronik (ITE) atau Pasal 310 KUHP atau Pasal 311 KUHP tentang pencemaran nama baik. Reaksi terhadap peristiwa yang dialami suaminya, yakni dimutasi atau diminta mengundurkan diri oleh atasan, EE menggunggah status tersebut di media sosial. Yang dilakukan atasan suami EE adalah mutasi secara sepihak oleh atasannya, artinya tidak sepersetujuan bawahan (suami EE) (Linangkung, 2014b).

Berdasarkan analisis semantik leksikal, kata-kata dalam unggahan EE yang diduga bermuatan mencemarkan nama baik adalah "lebay" dan "labil". "Lebay" merupakan kata dari bahasa gaul. Kata tersebut belum terdaftar dalam Kamus Besar Bahasa Indonesia. "Lebay" atau "lebeh" dipopulerkan pengguna ragam bahasa gaul pada 2006. Adapun makna "lebay" adalah berlebihan dan berkonotasi negatif (www.//http.arenasahabat, 2013). Berikutnya, kata "labil" dalam Kamus Besar Bahasa Indonesia daring (2016), bermakna sebagai berikut.

1 goyah; tidak mantap; tidak kokoh (tentang bangunan, pendirian, dan sebagainya); 2 goyang; tidak tenang (tentang kendaraan, kapal, pesawat terbang, dan sebagainya); 3 tidak tetap; mudah berubah-ubah; naik turun (tentang harga barang, nilai uang, dan sebagainya); 4 tidak stabil; cenderung berubah; 5 FIS tidak seimbang dan mudah berubah.

Berdasarkan analisis semantik leksikal, makna kata "labil" pada status EE bermakna tidak mantap, tidak kokoh tentang pendirian. Makna lain yang relevan adalah tidak stabil; cenderung berubah.

Berikutnya, hasil analisis semantik gramatikal adalah sebagai berikut. Dalam unggahan tersebut ditemukan frasa "yang nggak baik itu", artinya yang tidak baik kinerjanya dan tidak baik hatinya adalah "yang namanya Ayas dan Spv lainnya". Penyebutan nama "Ayas" langsung tertuju kepada sang pemilik nama, Spv yang bekerja di JJJ. Dalam unggahan status FB oleh EE, terdapat klausa "dia 204 | E-ISSN: 2527-8754 http:// journal.unesa.ac.id/index.php/Paramasastra 
nggak pantas dijadikan pimpinan Jolie Jogja Jewellery." "Dia" mengacu pada Ayas. Terdapat penilaian negatif terhadap kepemimpinan Ayas, yakni "Kami rasa dia nggak pantas dijadikan pimpinan Jolie Jogja Jewellery.” Dikatakan oleh "kami", yakni suami EE dan teman kerjanya bahwa Ayas tidak pantas menjadi pimpinan di JJJ. Kalimat berikutnya, "Banyak yang lebay dan masih labil seperti anak kecil!" Kalimat tersebut berdasarkan konteks unggahan bermakna gramatikal para atasan di JJJ ternyata berperilaku berlebihan dan mudah berubah pendirian. Mereka bagaikan anak kecil yang mudah dipengaruhi pendiriannya.

Hasil analisis berdasarkan teori tindak tutur terhadap tuturan EE tersebut adalah bahwa EE sebagai penutur dan rekan kerja suami EE sebagai petutur. EE menghasilkan tindak tutur ilokusi ekspresif. Di dalam data lingual tersebut, terdapat tidak tutur ilokusi ekspresif berupa pujian. Hal ini muncul dalam tuturan yang berbunyi, "Iya sih Pak Har baik." EE memuji Pak Har sebagai atasan yang baik. Berikutnya, EE mengekspresikan isi hatinya yang berbunyi, “... yang nggak baik itu yang namanya Ayas dan Spv lainnya. Kami rasa dia nggak pantas dijadikan pimpinan Jolie Jogja Jewellery. Banyak yang lebay dan masih labil seperti anak kecil!" diekspresikan di situ bahwa Ayas dan Spv lainnya tidak baik perilaku maupun kinerjanya. Mereka berkepribadian labil dan berlebihan laiknya anak kecil. Itulah tindak tutur ilokusi ekpresif EE.

Dari pihak petutur, yakni rekan kerja sang suami (Ayas) merasa nama baiknya dicemarkan oleh EE, karena curhat tersebut diunggah di media sosial Facebook. Sebagai tindak perlokusinya, petutur melaporkan EE ke Mapolda DIY, sesuai dengan lokasi perkara. Hal ini sejalan dengan kutipan yang berbunyi, “Ervani dilaporkan bekas atasan Alfa Janto ke Mapolda DIY pada 9 Juni 2014. Bekas atasan Alfa merasa tersinggung dengan status yang ditulis Ervani pada grup facebook toko aksesori tersebut, 30 Mei 2014” (dalam Linangkung, 2014a).

EE mengungkapkan isi hatinya tentang perlakuan tidak adil atasan sang suami. Sebagai mana disampaikan sang suami diberi ultimatun oleh atasan: dimutasi atau mengajukan pengunduran diri. Pada akhirnya, sang suami dimutasi tanpa sepersetujuan yang bersangkutan. Selanjutnya, berdasarkan hasil analisis, 
tuturan pada unggahan tersebut, utamanya "yang nggak baik", "kami rasa", “nggak pantas", "lebay”, “masih labil seperti anak kecil” merupakan ungkapan isi hati, bukan dengan sengaja dan sadar untuk menjelekkan atau mencemarkan nama baik atasan. Hal ini didukung oleh pernytaan bahwa majelis hakim membebaskan terdakwa dari segala dakwaan, karena unsur dengan sengaja mencemarkan nama baik dan/atau penghinaan tidak terpenuhi (dalam Prabowo, 2015).

\section{SIMPULAN}

Berdasarkan analisis yang telah dilakukan, simpulan yang disampaikan dalam tulisan ini adalah sebagai berikut.

1. Dari analisis semantik leksikal, ditemukan makna kata yang sebenarnya lepas dari konteks kalimat dan konteks wacana.

2. Dari analisis gramatikal, ditemukan makna kata yang bermakna gramatikal yang dipengaruhi oleh konteks kalimat dan konteks wacana sehingga dapat ditemukan makna tuturan yang dimaksudkan untuk menghina, mencemarkan, dan/atau menjelekkan nama baik ataukan tidak. Berdasarkan analisis tersebut, pihak terlapor dapat divonis melanggar UU ITE Nomor 11 Tahun 2008, khususnya pasal 27 ayat (3) ataukah tidak.

3. Dari analisis pragmatik, utamanya dengan teori tindak tutur, ditemukan tindak tutur ilokusi ekspresif (ungkapan kekecewan dan kemarahan) dan direktifprovokatif pada tuturan FS dan tindak tutur ekspresif EE (ungkapan isi hati) sebagai penutur serta tindak tutur perlokusi pada pihak petutur (LSM yang mewakili masyarakat Yogyakarta dan atasa suami EE) yang melaporkan keduanya ke kepolisian.

\section{DAFTAR RUJUKAN}

baranews.co/web/read/.../25.kasus.status.di.media.sosial.yang.berujung.ke.ranah. huku..Rabu, 03 September 2014 14:09 WIB | 204998. "25 Kasus Status di 
Media Sosial yang Berujung ke Ranah Hukum”. Diunduh pada 26 Juni 2016. Pukul 04.23.

Chaer, Abdul. 20009. Pengantar Semantik Bahasa Indonesia. Bandung: Rineka Cipta.

Coulthard, M. dan Alison Johnson (Eds.). 2010. An Introduction to Forensic Linguistics: Language in Evidence. New York: Rouledge.

Hanafi, Ristu. 2014a. "Tulis satus di Facebook, Ibu Rumah Tangga Dipenjara”. Jumat, 31 Oktober 2014. Diunduh pada 26 Juni 2016, pukul 04.50.

Hanafi, Ristu. 2014b. "Florence Tidak Ditahan Usai Sidang” 12 November 2014. Diunduh pada 26 Juni 2016, pukul 14.52.

Hanafi, Ristu. 2015a. "Sidang Florence, Ahli Bahasa Sebut Flo Menghina Warga Yogya”. Kamis, 15 Januari 2015. Diunduh pada Minggu, 26 Juni 2016, pukul 04.34 .

Hanafi, Ristu. 2015. "Banding Florence Sihombing Ditolak Pengadilan Tinggi Yogyakarta”. Minggu, 23 Agustus 2015, pukul 07.00 WIB. Diunduh pada Minggu, 26 Juni 2016, pukul 04.38.

http://www.arenasahabat.com/2013/05/kamus-kata-gaul-dan-alay-terbaruistilah.html. "Kumpulan Arti Kata Kalimat Gaul Terbaru 2016". Diunduh pada 3 Juli 2016, pukul 11.13.

Kamus Besar Bahasa Indonesia (KBBI) daring (dalam jaringan). 2016. Diunduh pada 2 Juli 2016, pukul 14.55.

Kitab Undang-Undang Hukum Pidana (KUHP). (Wetboek Van Strafrecht, Staatsblad 1915 No. 732).

Linangkung, Erfanto. 2014a. “Sidang Ervani Dilanjutkan Pekan Depan”. Selasa, 11 November 2014, pukul 15.12 WIB. Diunduh pada 26 Juni 2016, pukul 04.50 . 
Linangkung, Erfano. 2014b. "Penahanan Ditangguhkan, Ervani Menangis". Senin, 17 November 2014. Diunduh pada 26 Juni 2016, pukul 04.53.

Prabowo, Danang. 2015. "Penghina di Facebook Divonis Bebas”. Senin, 5 Januari 2015. Diunduh pada 26 Juni 2016, pukul 05.23.

Sitompul, Josua, 2012. Cyberspace, Cybercrimes, Cyberlaw: Tinjauan Aspek Hukum Pidana. Jakarta: Tatanusa.

Turrel, M.T. 2008. "Malcolm Coulthard and Alisom Johnson 2007: An Introduction to Forensic Linguistics: Language in Evidence". London and New York: Routledge. 237 pp. ISBN 978-0-415-32023

Undang-Undang Informasi dan Transaksi Elektronik (UU ITE) Nomor 11 Tahun 2008. 